Submitted on April 18, 2020.

\title{
Synthesis and properties of foam polyurethanes based on tall oil
}

\author{
(C) Svetlana Yu. Vasilyeva, Oleg E. Nasakin, ${ }^{+}$and Nikolay I. Koltsov* \\ Department of Physical Chemistry and Macromolecular Compounds. Chuvash State University \\ of I.N. Ulyanov. Moskovsky Ave., 15. Cheboksary, 428015. Chuvash Republic. Russia. \\ Phone: +7 (8352) 45-24-68. E-mail: koltsovni@mail.ru
}

\begin{abstract}
*Supervising author; ${ }^{+}$Corresponding author
Keywords: distilled melt oil, triethanolamine, polyurethane foams, synthesis, properties, application.

Abstract

The article presents the results of a study to obtain and study the properties of polyurethane foams, in which instead of a hydroxyl-containing component from petrochemical raw materials, it is proposed to use "green" raw materials based on distilled tall oil and triethanoamine. The influence of these components on the properties of the resulting polyurethane foams is analyzed. Polyurethane foams were prepared by mixing triethanolamine, tall oil, a catalyst - a $10 \%$ solution of sodium acetate in ethylene glycol, a foam stabilizer Penta 485, and an isocyanate-containing component (polymer diphenylmethane-4,4'-diisocyanate). The technological parameters of the synthesis process of polyurethane foams are determined, as well as the physicomechanical characteristics of the obtained polyurethane foams, such as apparent density, volume fraction of closed pores, compressive strength at $10 \%$ relative deformation, thermal conductivity and water absorption during exposure for 24 hours, and also determined average pore sizes of polyurethane foams using an optical microscope. It is shown that polyurethane foams based on tall oil and triethanolamine do not differ in their technological parameters and strength properties from polyurethane foams based on synthetic polyols. The volume fraction of closed pores for them is less in comparison with industrial samples of polyurethane foams, which indicates the possibility of using such polyurethane foam for insulation and noise insulation of residential buildings and industrial structures.
\end{abstract}

\section{References}

[1] F.G. Zhagfarov, P.O. Guskov, A.L. Lapidus. Trends in the processing of gas hydrocarbon feedstocks during the pyrolysis process. Gas chemistry. 2011. Vol.17. No.1. P.26-31. (russian)

[2] I.R. Khayrudinov. On the optimization of the process of pyrolysis of hydrocarbons and the efficient use of the resulting products. Butlerov Communications. 2009. Vol.17. No.6. P.53-59. ROI-jbc-02/09-17-6-53

[3] L. Maisonneuve, G. Chollet, E. Grau, H. Cramail. Vegetable oils: a source of polyols for polyurethane materials. Oilseeds and fats, Crops and Lipids. 2016. Vol.23. No.5. P.508-518. DOI: $10.1051 / \mathrm{ocl} / 2016031$

[4] M. Kumar, R. Kaur. Effect of Different Formulations of MDI on Rigid Polyurethane Foams based on Castor Oil. International Journal of Scientific Research and Reviews. 2014. Vol.5. No.11. P.29- 42.

[5] A.A. Nazirova, D.I. Fazylova, L.A. Zenitova, E.A. Kiyanenko. Polyurethane foam filled with fiberglass. Butlerov Communications. 2017. Vol.49. No.1. P.138-144. https://doi.org/10.37952/ROI-jbc-02/17-49-1138

[6] V. Sander. Natural resins, turpentine, tallow oil. Under. red B.D. Bogomolova. Publishing House: Forestry Industry. 1964. 420p. (russian)

[7] V. Yakushin, U. Stirna, O. Bkovens, M. Misane, I. Sevastyanova, D. Vilsone. Syntesis and Characterization of Novel Polyurethanes Based on Tall Oil. Materials Science. 2013. Vol.19. No.4. P.390-396. DOI:10.5755/j01.ms.19.4.2666

[8] R.A. Ragimov. Ammonium salts of acid fractions of rapeseed oil. Chemistry of plant raw materials. 2015. No.2. P.97-105. (russian)

[9] N.E. Marcovich, M. Kuranska, A. Prociak, E. Malewska, K. Kulpa. Open cell semi-rigid polyurethane foams synthesized using palmoil-based bio-polyol. Industrial Crops and Products. 2017. Vol.102. P.88-96.

[10] A.A. Berlin, F.A. Shutov. Foam polymers based on reactive oligomers. Moscow: Chemistry. 1978. 296p. (russian)

[11] S. Fernández, C. Peña-Rodríuez, A. Prociak, M.A. Corcuera, A. Eceiza. Tailoring Mechanical Properties of Rigid Polyurethane Foams by Sorbitol and Corn Derived Biopolyol Mixtures. ACS 
Sustainable Chemistry and Engineering. 2015. Vol.3. No.12. P.3382-3387.

DOI:10.1021/acssuschemeng.5b01094

[12] M. Gravit, A. Kuleshin, E. Khametgalieva, I. Karakozova. Technical characteristics of rigid sprayed PUR and PIR foams used in construction industry. IOP Conference Series: Earth and Environmental Science. Energy Management of Municipal Transportation Facilities and Transport - EMMFT 2017. 10-13 April 2017. Vol.90. P.2-7.

[13] Ch. Zhang, J. Li, F. Hua Zh, Zhu, Yu. Huang. Correlation between the acoustic and porous cell morphology of polyurethane foam: Effect of interconnected porosity. Materials and Design. 2012. Vol.41. P.319-325. 